\title{
First assessment of the conservation status of the jaguar Panthera onca in the Sierra Madre de Chiapas, Mexico
}

\author{
J. Antonio De La Torre, Marina Rivero, Gamaliel Camacho \\ Luis Arturo Álvarez-Márquez and Rodrigo A. Medellín
}

\begin{abstract}
Although the Near Threatened jaguar Panthera onca ranges from the south-west USA to central Argentina, populations outside Amazonia are generally small and isolated. One such area, the Sierra Madre de Chiapas in the state of Chiapas, Mexico, is potentially an important area for jaguar conservation but information on the species in this region is limited and its conservation status is unknown. In this study we documented the occurrence and abundance of jaguars in the Sierra Madre de Chiapas complex. We compiled all available records of the species within the region and conducted a camera-trap survey during August 2015December 2016. Interviews were conducted to determine the perception of the jaguar by cattle owners and to obtain information on any livestock predation. We found that jaguars still occur throughout the Sierra Madre de Chiapas landscape, including the plains on the Pacific Coast of Chiapas, but its abundance in the region is low. On the basis of our findings we have incorporated the Sierra Madre de Chiapas in Mexico's National Jaguar Conservation Strategy, and recommend that international organizations include this area in their priorities for jaguar conservation. To improve coexistence between jaguars and the communities of the Sierra Madre de Chiapas, strategies need to be developed, in collaboration with the local communities, to improve livestock practices for reduction of predation by jaguars, to strengthen government conservation policies and to implement educational and communication programmes about the importance of this species in the region.
\end{abstract}

Keywords Camera trap, conservation, Mexico, occurrence, Panthera onca, Sierra Madre de Chiapas

\footnotetext{
J. ANTONIO DE LA TORRE* (Corresponding author) Instituto de Ecología, Universidad Nacional Autónoma de México, Ciudad Universitaria, 04318, Ciudad de México, México. E-mail adelatorre@iecologia.unam.mx

Marina Rivero* El Colegio de la Frontera Sur, Departamento de Conservación de la Biodiversidad, Lerma, Campeche, Mexico

Gamaliel Camacho Bioconciencia A.C., Ciudad de México, México

Luis Arturo Álvarez-Márquez Área de Protección de los Recursos Naturales La Frailescana, CONANP, México

Rodrigo A. MedelLín Instituto de Ecología, Universidad Nacional Autónoma de México, Ciudad Universitaria, Ciudad de México, México

*Also at: Bioconciencia A.C., Ciudad de México, México

Received 11 January 2018. Revision requested 6 March 2018. Accepted 12 April 2018. First published online 27 September 2018.
}

A lthough the jaguar Panthera onca, categorized as Near A Threatened on the IUCN Red List (Quigley et al., 2017), ranges from the south-west USA to central Argentina, populations outside Amazonia are generally small and isolated (de la Torre et al., 2018). One such area, the Sierra Madre de Chiapas in the state of Chiapas, Mexico, is potentially an important area for jaguar conservation but information on the species in this region is limited. To provide information for Mexico's National Jaguar Conservation Strategy, we document here the occurrence and abundance of the species in this region.

The Sierra Madre de Chiapas (Fig. 1) is one of the most biodiverse regions in Mexico, with tropical rainforest, montane cloud forest, pine-oak forest, and tropical deciduous forest (Pérez-Farrera et al., 2006). The complex of the Sierra Madre de Chiapas comprises the Natural Resources Protection Area La Frailescana $\left(1,775 \mathrm{~km}^{2}\right)$ and two Biosphere Reserves, El Triunfo $\left(1,191 \mathrm{~km}^{2}\right)$ and La Sepultura $\left(1,673 \mathrm{~km}^{2}\right)$. The terrain is rugged and steep, with altitudes of $280-2,600 \mathrm{~m}$. Climate is tropical to subtropical, with a rainy season in May-October. Mean annual temperatures are $22-26^{\circ} \mathrm{C}$, and mean annual rainfall is $1,200-2,000 \mathrm{~mm}$ at mid-low altitudes and $4,000 \mathrm{~mm}$ at the highest altitudes.

We compiled all available historical records for the species in the region from the National System of Information on Biodiversity. Additionally, we include confirmed records of individuals that were poached and confirmed records of jaguar signs. To document the jaguar's current presence in the region we deployed 55 camera-trap stations during August 2015-December 2016 in c. $420 \mathrm{~km}^{2}$ of the Natural Resources Protection Area La Frailescana. Camera traps were installed at a height of $40 \mathrm{~cm}$ from the ground and distances between camera-trap stations were $385-3,373 \mathrm{~m}$ (mean distance $1,073 \pm \mathrm{SD} 753 \mathrm{~m}$ ). Total sampling effort was 9,274 trap-days. Individual jaguars detected were identified in the images and videos by the pattern of their pelage (Silver et al., 2004).

To make a rapid assessment of the perception of the jaguar by the local communities and to obtain information on any jaguar predation on domestic animals, we interviewed 102 cattle owners in the Natural Resources Protection Area La Frailescana. We used a semi-structured questionnaire with three sections: knowledge about jaguars, cattle loss and perceptions (Table 1). 


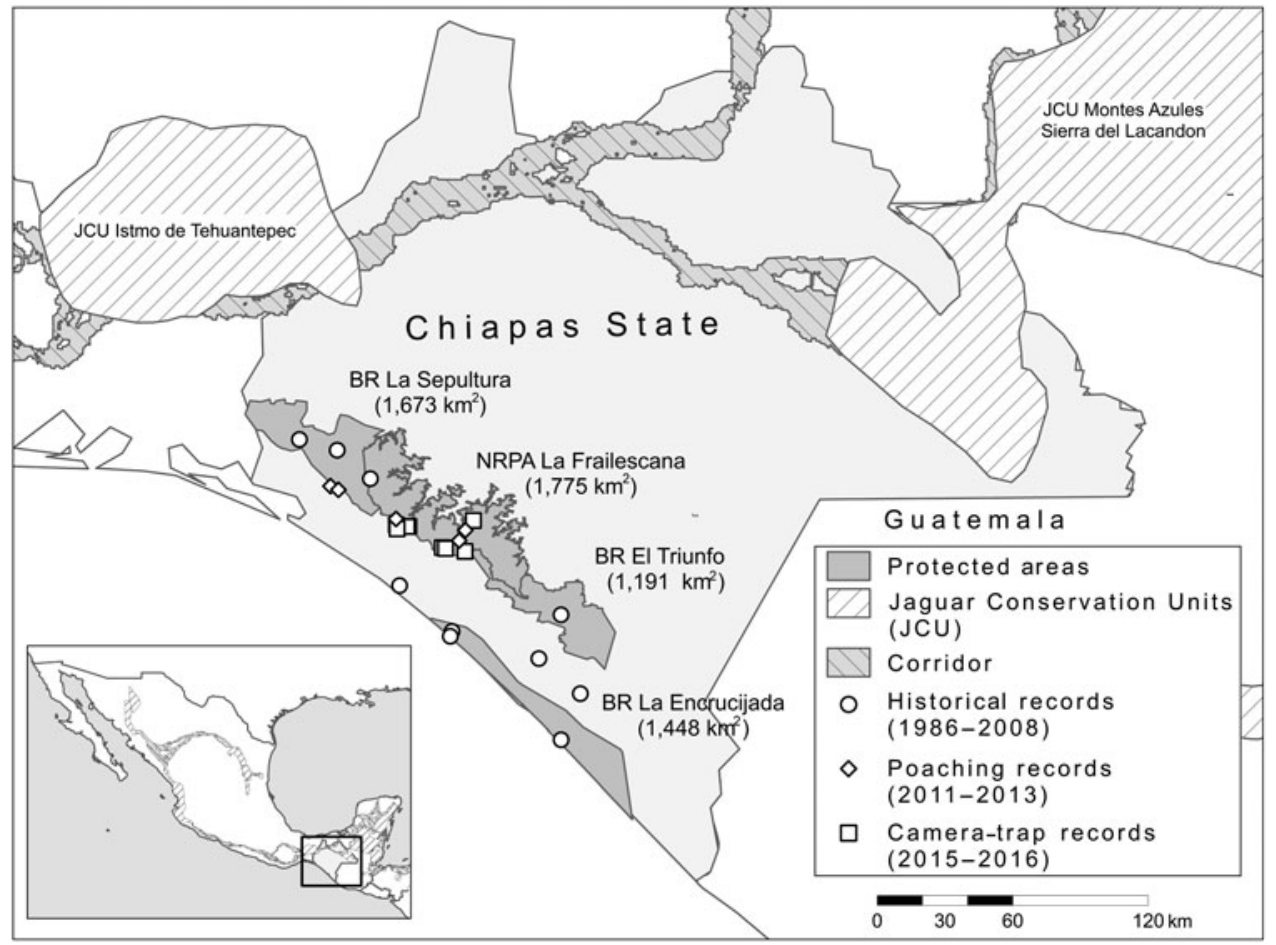

FIG. 1 Protected areas of the Sierra Madre de Chiapas landscape (Biosphere Reserves (BR) La Sepultura, El Triunfo and La Encrucijada, and Natural Resources Protection Area (NRPA) La Frailescana), jaguar Panthera onca records in this region, and Jaguar Conservation Units and the network of jaguar corridors modelled for the region (Rabinowitz \& Zeller, 2010).
We obtained 11 records of jaguars for 1986-2008 (Muñoz \& March, 2003; Lorenzo Monterrubio et al., 2005; Morales Pérez, 2005; Fig. 1), at altitudes of $0-1,632 \mathrm{~m}$ in the Sierra Madre de Chiapas region and the neighbouring coast of Chiapas (Fig. 1), which was originally tropical rainforest and mangroves but is now mostly deforested (Aranda, 1996). We obtained four confirmed records of jaguars killed, three in retaliation for predation of domestic animals in 2012-2013 and one poached in 2011. Jaguar capture rate across all camera stations was 0.97 per 1,000 trap-days. We identified three male and two female jaguars, and we recaptured three of these individuals. These records were over $1,120-1,758 \mathrm{~m}$, from montane cloud forests and oak forests.

The interviews indicated that the jaguar is well known. More than half of the interviewees had either seen dead jaguars or observed them in the wild, and most of the interviewees had lost some cattle. However, only $10 \%$ of these losses were attributed to predation by large felids; $77 \%$ were a result of illness or accidents. Jaguars were the main species identified as the predator of cattle $(29 \%)$ but other wildlife also caused significant loss (40\%; Table 1). Although the interviewees considered the jaguar's presence beneficial for ecosystem functioning, many people felt that jaguars were the predator mostly responsible for their loss of cattle (Table 1).

A landscape strategy for jaguar conservation in the Sierra Madre de Chiapas would need to include areas with suitable jaguar habitat, such as the coast of Chiapas, which includes the Encrucijada Biosphere Reserve and adjacent areas of primary forest (Aranda, 1996). Considering the large spatial requirements of jaguars (de la Torre et al., 2017) it is likely that individuals are moving between the Sierra Madre de Chiapas and adjacent areas (Fig. 1). This complex, together with the Encrucijada Biosphere Reserve and adjacent areas, encompasses c. $5,500 \mathrm{~km}^{2}$ of primary forest, sufficient to maintain a population of jaguars (Rodríguez-Soto et al., 2011). However, the limited number of historical records that we located indicates that the jaguar population in this region is sparse, and our camera-trap survey indicates that abundance in the region is low compared to other areas in Central America (Silver et al., 2004; de la Torre \& Medellín, 2011; Chávez et al., 2016).

International jaguar conservation strategies have not previously included the Sierra Madre de Chiapas (Fig. 1), and the region was excluded from the Jaguar Conservation Units and corridors that were defined to establish continental priorities to conserve the species (Sanderson et al., 2002; Rabinowitz \& Zeller, 2010). Our results indicate that the species is still present in the region, and we have therefore included the Sierra Madre de Chiapas in Mexico's National Jaguar Conservation Strategy (CONANP, 2009; Zarza et al., 2013; Ceballos et al., 2016), and we recommend that international organizations include this area in their priorities for jaguar conservation.

We found that local perceptions of the jaguar included fear and respect, and jaguars were considered harmful and dangerous, but most interviewees believed that the jaguar should be preserved. Although most cattle owners noted that jaguar conservation in the region is not their responsibility, some showed an interest in implementing actions to 
TABLE 1 Percentage of responses (of 102 cattle owners interviewed) to questions regarding knowledge about jaguars, the main causes of livestock loss, and perceptions about jaguars in the Natural Resources Protection Area La Frailescana (Fig. 1).

\begin{tabular}{|c|c|c|c|c|c|}
\hline Question & Answer & $\%$ & Complementary question & Answer & $\%$ \\
\hline \multicolumn{6}{|l|}{ Knowledge about jaguars } \\
\hline \multirow{2}{*}{$\begin{array}{l}\text { Can you recognize the jaguar } \\
\text { through cards? }\end{array}$} & Yes & 83 & & & \\
\hline & No & 17 & & & \\
\hline \multirow{4}{*}{$\begin{array}{l}\text { Have you seen a jaguar either } \\
\text { dead or alive? }\end{array}$} & Yes & 51 & How long ago did you see a & $<1$ year & 8 \\
\hline & & & jaguar? & $1-10$ years & 63 \\
\hline & & & & $>10$ years & 29 \\
\hline & No & 49 & & & \\
\hline \multirow{5}{*}{$\begin{array}{l}\text { Have you killed or heard that } \\
\text { someone else has killed a jaguar? }\end{array}$} & Yes & 30 & How many jaguars have you & 1 jaguar & 60 \\
\hline & & & killed or heard to have been & 2 jaguars & 11 \\
\hline & & & killed? & 3 jaguars & 14 \\
\hline & & & & 4 jaguars & 14 \\
\hline & No & 70 & & & \\
\hline \multicolumn{6}{|l|}{ Livestock loss } \\
\hline \multirow[t]{8}{*}{ Have you ever had loss of livestock? } & Yes & 66 & Which were the main causes of & Illness & 42 \\
\hline & & & loss of livestock? & Accident & 34 \\
\hline & & & & Predation by large carnivores & 10 \\
\hline & & & & Parturition & 8 \\
\hline & & & & Drought & 3 \\
\hline & & & & Theft & 2 \\
\hline & & & & Misplacement & 1 \\
\hline & No & 34 & & & \\
\hline \multirow{11}{*}{$\begin{array}{l}\text { Have you ever suffered cattle loss } \\
\text { from wildlife? }\end{array}$} & 1 species & 30 & What kind of wildlife attacked & Jaguars & 29 \\
\hline & $>1$ species & 60 & your cattle? & Vampire bats & 20 \\
\hline & & & & Venomous snakes & 20 \\
\hline & & & & Puma & 17 \\
\hline & & & & Coyote & 7 \\
\hline & & & & Other & 6 \\
\hline & & & How did you identify the animal & Footprints & 60 \\
\hline & & & that attacked your cattle? & $\begin{array}{l}\text { Marks left by the predator } \\
\text { on the dead cattle }\end{array}$ & 20 \\
\hline & & & & Dung or signs of burial & 13 \\
\hline & & & & Sighting & 7 \\
\hline & No & 8 & & & \\
\hline \multicolumn{6}{|l|}{ Perceptions } \\
\hline \multirow{6}{*}{$\begin{array}{l}\text { What does the word jaguar mean } \\
\text { to you? }\end{array}$} & Fear & 60 & & & \\
\hline & Respect & 16 & & & \\
\hline & Admiration & 12 & & & \\
\hline & Danger & 6 & & & \\
\hline & Risk of extinction & 3 & & & \\
\hline & Harmless & 3 & & & \\
\hline \multirow{2}{*}{$\begin{array}{l}\text { Do you think the presence of the } \\
\text { jaguar in the region is beneficial } \\
\text { for you? }\end{array}$} & Yes & 60 & & & \\
\hline & No & 40 & & & \\
\hline
\end{tabular}

minimize jaguar predation of cattle. Rearing of livestock is one of the main economic activities in the areas adjacent to jaguar habitat in the region, and retaliatory killing of jaguars in response to attacks on cattle (Treves \& Bruskotter, 2014) could be one of the main reasons for the low abundance of jaguars in this region. To improve coexistence between jaguars and the communities of the Sierra Madre de Chiapas, strategies need to be developed, in collaboration with the local communities, to improve livestock practices for reduction of predation by jaguars (Azuara et al., 2010), to strengthen government conservation policies, and to implement educational and communication programmes about the importance of this species in the region.

Acknowledgements We thank our field assistants from the Sierra Madre de Chiapas for their help, the administration of the Natural Resources Protection Area La Frailescana, especially S. Nañez, M. Morales and R. Diaz-Velazquez, SNIB-CONABIO for providing information for this study, Maria de Jesús Teniente and Laura Navarro from Bioconciencia A.C., and Paulina Arroyo, Lidia García-Gutierrez, Juan Luis Peña-Mondragón and Ivonne Cassaigne for their support. 
This work was supported by the Conservation Program of Endangered Species of CONANP-Mexico, the NRPAF, and Bioconciencia A.C.

Author contributions Study design: JAT, MR and LAM; compilation of information and first draft: JAT; contribution to writing: MR; compilation of information on jaguar distribution: GM and LAM; review of the data and direction of revisions: JAT and MR; revision of the manuscript: RAM.

\section{Conflicts of interest None.}

Ethical standards All interviews abided by the ethical standards of the Social Research Association.

\section{References}

Aranda, M. (1996) Distribución y abundancia del jaguar, Panthera onca (Carnivora; Felidae) en el estado de Chiapas, México. Acta Zoológica Mexicana, 68, 45-52.

Azuara, D., Manterola, C., Pallares, E., Soler, A., Rivera, A., Cassaigne, I. et al. (2010) Protocolo de atención a conflictos con felinos silvestres por depredación de ganado. Comisión Nacional de Áreas Naturales Protegidas-Secretaría de Medio Ambiente y Recursos Naturales, Ciudad de México, México.

Ceballos, G., Zarza, H., Chávez, C. \& González-Maya, J.F. (2016) Ecology and conservation of jaguars in Mexico: state of knowledge and future challenges. In Tropical Conservation: Perspectives on Local and Global Priorities (eds A. Aguirre \& R. Sukumar), pp. 273-289. Oxford University Press, New York City, USA.

Chávez, C., Zarza, H., de la Torre, J.A., Medellín, R.A. \& Ceballos, G. (2016) Distribución y estado de conservación del jaguar en México. In El Jaguar en el Siglo XXI: La Perspectiva Continental (eds R.A. Medellín, J.A. de la Torre, H. Zarza, C. Chávez \& G. Ceballos), pp. 47-92. Fondo de Cultura Económica, Universidad Nacional Autónoma de México, Ciudad de México, México.

CONANP (2009) Programa de Acción para la Conservación de la Especie: Jaguar (Panthera onca). Comisión Nacional de Áreas Naturales Protegidas. Secretaría de Medio Ambiente y Recursos Naturales, Ciudad de México, México.

de la Torre, J.A., Gonzalez-Maya, J.F., Zarza, H., Ceballos, G. \& Medellín, R.A. (2018) The jaguar's spots are darker than they appear: assessing the global conservation status of the jaguar Panthera onca. Oryx, 52, 300-315.

De la Torre, J.A. \& Medellín, R.A. (2011) Jaguars Panthera onca in the Greater Lacandona Ecosystem, Chiapas, Mexico: population estimates and future prospects. Oryx, 45, 546-553.

de la Torre, J.A., Núnẽez, J.M. \& Medellín, R.A. (2017) Spatial requirements of jaguars and pumas in Southern Mexico. Mammalian Biology, 84, 52-60.

Lorenzo Monterrubio, A.M.C., Bolaños Citalán, J.E. \& Barragán Torres, F. (2005) Actualización de la base de datos de la colección mastozoológica de El Colegio de la Frontera Sur, San Cristóbal de las Casas. El Colegio de la Frontera Sur, Unidad San Cristóbal de las Casas, Bases de datos SNIB-CONABIO proyecto No. AAoo3, Ciudad de México, México.

Morales Pérez, J.E. (2005) Vertebrados terrestres del Corredor Biológico Sierra Madre del Sur, Chiapas, México. Instituto de Historia Natural y Ecología, Dirección de Investigación Miguel Álvarez del Toro, Bases de datos SNIB-CONABIO proyecto No. Yo21, Ciudad de México, México.

Muñoz Alonso, L.A. \& March Mifsut, I.J. (2003) Actualización y enriquecimiento de las bases de datos del proyecto de evaluación y análisis geográfico de la diversidad faunística de Chiapas. El Colegio de la Frontera Sur, Bases de datos SNIB-CONABIO proyectos No. Uo14 y P132, Ciudad de México, México.

Pérez-Farrera, M.A., Meléndez-López, E., Sarmiento, O.F., Moreno, N.L. \& Najarro, F.H. (2006) Inventario florístico de la zona de protección forestal la Frailescana (zona focal), Chiapas, Mexico, Universidad de Ciencias y Artes del Estado de Chiapas, Informe Final SNIB-CONABIO, proyecto No. Yo12, Ciudad de México, México.

Quigley, H., Foster, R., Petracca, L., Payan, E., Salom, R. \& Harmsen, B. (2017) Panthera onca. In The IUCN Red List of Threatened Species 2017: e.T15953A50658693. Http://dx.doi.org/10. 2305/IUCN.UK.2017-3.RLTS.T15953A50658693.en [accessed 18 May 2018].

Rabinowitz, A. \& Zeller, K.A. (2010) A range-wide model of landscape connectivity and conservation for the jaguar, Panthera onca. Biological Conservation, 143, 939-945.

Rodríguez-Soto, C., Monroy-Vilchis, O., Maiorano, L., Boitani, L., Faller, J.C., Briones, M.Á. et al. (2011) Predicting potential distribution of the jaguar (Panthera onca) in Mexico: identification of priority areas for conservation. Diversity \& Distribution, 17, 350-361.

Sanderson, E.W., Redford, K.H., Chetkiewicz, C.B., Medellin, R.A., Rabinowitz, A.R., Robinson, J.G. \& Taber, A.B. (2002) Planning to save a species: the jaguar as a model. Conservation Biology, 16, 58-72.

Silver, S.C., Ostro, L.E.T., Marsh, L.K., Maffei, L., Noss, A.J., Kelly, M.J. et al. (2004) The use of camera traps for estimating jaguar Panthera onca abundance and density using capture/ recapture analysis. Oryx, 38, 148-154.

Treves, A. \& Bruskotter, J. (2014) Tolerance for predatory wildlife. Science, 344, 476-477.

Zarza, H., ChÁvez, C. \& Ceballos, G. (2013) Importancia de las iniciativas regionales para la consolidación de una estrategia nacional de conservación de jaguar: el caso de México. In El Plan de Conservación de Felinos del Caribe Colombiano: Los felinos y su papel en la planificación regional integral basada en especies clave (eds C. Castaño-Uribe, J.F. González-Maya, D. Zárrate-Charry, C. Ange-Jaramillo \& I.M. Vela-Vargas), pp. 191-201. Fundación Herencia Ambiental Caribe, Pro CAT Colombia, The Sierra To Sea Institute, Santa Marta, Colombia. 